\title{
Reader-Response Theory and Dialogic Analysis of Gerald Vizenor's The Heirs of Columbus
}

\author{
Ghazala Rashid $^{1} \&$ Ali Ahmed Kharal ${ }^{1}$ \\ ${ }^{1}$ Department of English, National University of Modern Languages, H-9 Islamabad, Pakistan \\ Correspondence: Ghazala Rashid, Department of English, National University of Modern Languages, H-9 \\ Islamabad, Pakistan. Tel: 92-320-858-0540. E-mail: ghazalarashidalam@gmail.com
}

Received: June 17, 2019 Accepted: July 10, 2019 Online Published: July 23, 2019

doi:10.5539/ijel.v9n4p399 URL: https://doi.org/10.5539/ijel.v9n4p399

\begin{abstract}
This article has employed the theory of Bakhtin's (1895-1975) dialogism, and Wolfgang Iser's (1926-2007) reader-response theory to examine the socio-political, and historical implications of Gerald Vizenor's The Heirs of Columbus. The Heirs of Columbus (Heirs) was written to dismantle the historical oppression of Native Americans (NA) throughout the post Columbian era. Dialogism is an umbrella term that creates difference between historical and Native American discourse, providing new passages to comprehend the marginalized silenced other; in other words, it helps create a voice for the vanishing Indian. We have systematically identified the use of dialogic techniques like subversion, carnival, polyphony and heteroglossia in Heirs while, at the same time, analyzing his text through the framework of Iser's reader-response theory. We have come to the conclusion that Iser's theory is not enough to analyze Vizenor's revolutionary text since Vizenor provokes his readers to draw their own conclusions rather than conforming to set of fixed ideals of author.
\end{abstract}

Keywords: dialogism, hybridization, heteroglossia, reader's response, discourse

\section{Introduction}

Vizenor's (1934-) Heirs is a subverted, mythical account of the discovery of America by Christopher Columbus that revolves around the themes of NA discrimination and oppression by the western world, re-connecting with tribal ethnic identity, and survivance (Vizenor \& Vizenor, 1991). It presents the NA heirs i.e., Binn Columbus, Stone Columbus, Felipa, and Miigis flowers who are interested in recovering the human remains of Pocahontas, and their father Christopher Columbus. In his work, "The Dialogic Imagination: Four Essays", Bakhtin (2010) emphasizes the importance of dialogue in language and text. According to him, we must open up to the possibility of dialogue, and alternative perspectives to break away from the tyranny of authoritative or monologic discourse. The purpose of a dialogic text is not only to create freedom of speech in the text, giving its readers a more realistic experience, it also provides and opens up the possibility of a better understanding of the text itself. It gives hope to the oppressed and misinterpreted voices that were otherwise, left unheard or overlooked in the realm of monologism (Baron, 2016). Therefore, the Native American (NA) literature is an ideal genre to be analyzed using the theoretical framework of dialogism and reader's response theory since the writers of Native American literature are the proponents of the world of periphery, and also because these writers have to face issues like dual nationality, and are victims of stereotypical identity even though, they are an integral part of American historical landscape (Carmack, Gasco, \& Gossen, 2016). Native Americans are the indigenous people who have a rich and vast historic connection with America; however, they have been subjected to centuries of displacement, relocation, and subjugation by the Eurocentric 'White' nation. The entire history of Native Americans is filled with power tussle with western invaders over the land. The strategic methods of oppression included forced conversions to Christianity, condemning tribal rituals, and the construction of reservations on the least desirable parts of land for natives (Mielke, 2018). Misinterpreting and molding the NA identity to benefit Western agenda is, however, the greatest mark of injustice done by western invaders.

The work created by the Native American writers, in general, is symbolic of a hybridized ethnic identity, inculcated with primitive oral traditions that are still celebrated in the Native American world today (Barry, 2002). Gerald Vizenor is mixed blood, White Earth, Native American writer whose work strives to recreate and regenerate NA identity that can withstand and counterbalance the falsifications created by western dominated 
contemporary world. He has used subversion, heterogeneity and agnostic humor in his novels to describe the ethnic identity of the Native Americans. Therefore, these narratives provide us diverse, and vibrant accounts of NA culture while accomplishing the deconstruction of the Eurocentric literary canons (monologism). Speaking specifically about The Heirs of Columbus, Vizenor's work has been identified in this study to possess dialogic aspects, to shatter the monologic frame of thought, and in the process, change the readers' opinion by providing alternative perspectives to them.

\subsection{Familiarizing with the Problem}

The novel under scrutiny, The Heirs of Columbus is a true representative of Gerald Vizenor's work as a struggling Native American, and it also enlightens the readers about the subversive and carnivalesque nature of NA literature. Although Rebecca M. Lush (2012) has examined the role of sexuality and language games in Heirs, we have not found a single work that focuses on encompassing all the dialogic aspects present in Vizenor's selected novel (a thorough Literature Review is presented in section 2). As discussed earlier, the true identity of Native Americans has been subjected to stereotypical representation by the Western literary society, and Vizenor's work mainly aims to restore the NA identity to its original grandeur. We have linked the dialogic aspects in Vizenor's work with the socio-political scenario of Native American history of subjugation which has not been done as yet. Vizenor has used ambivalence, carnival, polyphony, and heteroglossia in his text and left intentional gaps in the story to provoke his readers' curiosity and set them free from the monologic literary catacombs embedded in their minds. Consequently, we have used Iser's reader-response theory, to understand the link between Vizenor's dialogic text, and its impact on readers; how far has he succeeded in shattering monologic frame of thought. We have picked a relatively old novel and analyzed it through a collaborative research approach that provides a fresh perspective on how dialogism has aided Vizenor in restoring NA identity to its former glory in literature.

\subsection{Significance of the Problem}

This paper has highlighted dialogic aspects present in Vizenor's Heirs, in light of NA socio-political, and cultural backdrop, employing reader-response theory. Dialogism is ubiquitous in approach and it is not just limited to literature; according to the theorist Bakhtin (2010), all language and thought processes are dialogic. Everything that is ever uttered or communicated in these languages by anyone, in reaction or in anticipation of things vice versa is interrelated and dynamic. These views are, as Bakhtin considers, persistently involved in the re-description and evolution of the literary world. Additionally, the process of redefinition or re-description of the world is very crucial to the Native American writers and novelists to restore their NA identity. The aim of Native American writers is not just to create a dialogic discourse, instead, they have to create a text that reinforces an identity that is vibrant, dynamic and can survive the harshness of the contemporary world. In Heirs, Vizenor (1991) has subverted the stereotypical, monologic accounts by using grotesque humor and imaginative metaphors while replacing the real entries from the journal, written and kept by Christopher Columbus, with the ambivalent, parodist encounters with natives. Thereby forcing the reader to examine and re-examine the text to grasp its true meaning and establish a dialogic perspective towards the history of America.

\section{Literature Review}

Most of the research done on Heirs is based on postmodernist theory and trickster discourse. The work by Barry (2002) has analyzed the literary works of Gerald Vizenor from the postmodernist context. She has proposed that the symbolic representation of Bears in Chippewa traditions and religions holds key importance in Vizenor's works. Similarly, Hockbruck (1992) has emphasized that Vizenor's work tends to 'breakaway' from the established norms of language and literary works that were previously deemed characteristic to Native American narratives by critics. Russo (2017) contends that Vizenor has employed techniques code-switching technique and multi-voiced narrative to archive linguistic transmotion in The Heirs of Columbus. Therefore, none of the above-cited works have shed light on either dialogic content or the socio-political perspectives behind The Heirs of Columbus. We aim to enlighten the reader with the dialogic aspects of The Heirs of Columbus and also provide the socio-political background of Native American history that has driven Vizenor into writing the said narrative.

The circle of Native American literature is ever expansive and requires constant pruning since it is still undergoing the developmental stages. Early attempts of writing by the Native American writers were mainly done to oppose or negate their established monologic 'stagnant' identity and explain the stance of Native Americans in the history of Eurocentric literature. Bleaser (1996) writes that the NA community has been deeply aggrieved by misinterpretation of their personality in literary works; their mischievous, humorous, and playful identity has been replaced with serious, authoritative, and hardcore traits. Therefore, stereotyping of Native 
identity has been strongly addressed by NA writers and often replaced with revolutionary ideals. Michael Fischer (1986) states, "Ethnicity is not something that is simply passed on from generation to generation, taught and learned; it is something dynamic, often unsuccessfully repressed or avoided". Contemplating the dynamics of such an identity is, therefore, crucial to develop a proper understanding of the Native American perspective in literature. Native literature, as Fischer (1986) explains, can initiate for readers, "a dialectical or two-sided journey examining the realities of both sides of cultural differences so that they may mutually question each other, and thereby generate a realistic image of human possibilities and self-confidence for the explorer grounded in comparative understanding rather than ethnocentrism".

Gerald Vizenor is motivated to bring forth a body of text that is dependent on concepts like ethnicity, victimization, hybridization, social, and political persecution; he aims to bring forth a voice that can bridge the gap between the western world and the Native American indigenous world. Gerald Vizenor has also applied the postmodernist paradigms in his literary works; he differs from other writers of his era in his mediational approach towards NA oppression and his use of carnivalesque discourse to counter the grave realities of NA history. He deliberately creates a text that will be difficult to grasp by the reader in order to make them look for alternative approaches to understand the content and context behind it. The creation of a sovereign state in Heirs, one that celebrates tribal heritage and heals the wounded, abused children using genes of Christopher Columbus, at the end of the novel leaves the reader on a positive note. He sympathizes with Columbus in epilogue and believes that "Christopher Columbus, no doubt, would rather be remembered as an obscure healer in the humor of a novel and crossblood stories than a simulated quiver in national politics" (Vizenor, 1991).

This paper aims are to identify the dialogic elements in Heirs, helpful in dealing with the issues related to hybridity and multiple ethnicities that have not been scrutinized by previous research to the best of our knowledge.

\subsection{Theoretical Foundation}

The discerning factor about the NA literature is that it is deeply rooted with the issues concerning ethnic identity, nationalism; it also includes various literary theories like dialogism and reader-response theory of Wolfgang Iser. Therefore, the theoretical framework employed in this paper to critically analyze the selected novel involves a collaborative approach. By collaborative approach, we refer to combining the individual theories of Bakhtin's dialogism and Iser's reader-response criticism into a single theoretical framework for the investigation of selected work. Let us briefly elaborate on the collaborative approach before delving towards the dialogical aspects of the selected novel.

\subsection{Why a Collaborative Approach?}

In our society we are often challenged with binaries; opposition coexists in specific forms; provoking questions like yes or no, right or wrong, men or women, up and down, good or evil, and civilization versus barbarianism. Due to these binaries, we are inclined towards only two-sided opinions however, Vizenor transgresses " $\ldots$ they don't really absorb each other, do they? We hold them as opposites ... force them to continue the dialectic" (Bleaser, 1996). Therefore, the problem lies with the dichotomous way of thinking that incites boundaries in the consciousness like good versus evil, black versus white, and right versus wrong etc., providing a Manichean ideology. However, the text provided by Gerald Vizenor is free from such constraints since such Manichean ideology only incites binary opposites in the society.

According to him, a dialogic text has more potential to create multiple interpretations as he states that, "Any 'living event' must to a greater or lesser degree remain open"; this makes the text prone to generate multiple opinions and alternative perspectives, thereby making the text ambiguous, pre-suggestive, and open to limitless stylistic possibilities and engenders active participation on the part of the readers. These alternative perspectives provoke reader's response which is purely based on his experiences, context and mental filter, restraining him from being conclusive about the interpretation of the text.

Kimberly Bleaser writes about Vizenor's intentional use of ambiguous and discursive language in his writing by quoting his words in one of his interviews: "literature ought to confront the comfortable values of authority. What other good is there for literature but to heal ourselves?" (Bleaser, 1996). According to her, at a certain juncture, Vizenor purposely writes in ambiguous style, creating confusion and indefiniteness in the minds of readers, forcing them to look for hidden meaning behind the text. Therefore, reading his novels is an interactive process that involves the readers in a literary process. The text created by Vizenor is labyrinthine, the subject matter, content, historic references and diction; everything is over complicated and deeply meaningful; the deconstruction of form and content is also part of his ambiguous text. Kimberley Bleaser states that his difficult style resists what he calls the "consumer mentality of the arts", and he is perpetually trying to challenge the 
authority and the "terminal creeds" (a term coined by Vizenor to describe static ideologies of the society). He wants to question every comfortable niche of our consciousness to liberate ourselves from the stereotyping and to "push the consciousness" of the reader (Bleaser, 1996). Vizenor relies heavily on his active readers' imagination to fill the gaps in his stories with their own perception of the truth and in doing so liberate themselves from monologic contingencies. Therefore, single theory is not sufficient to fully comprehend Vizenor's work since it is multiple voiced discourse encompassing heterogeneity, polyphony, carnival, and heteroglossia. This is the reason that Bakhtin's dialogism along with Wolfgang Iser's reader-response theory has been employed to perform analysis of Vizenor's selected work.

\subsection{Bakhtin's Interpretation of Dialogue}

Mikhail Bakhtin, having faced the oppressive rule of Stalin (1878-1953), gave birth to the concept of dialogism in the novel to celebrate freedom of thought by introducing dialogue in text. In Bakhtin's dialogic novel, the readers "are to be led step by step from the popular view ... to the truth which is merely and purely theoretical, guided by certain obtrusively enigmatic features in the presentation of the popular teaching - obscurity of the plan, contradictions, pseudonyms, inexact repetitions of earlier statements, strange expressions, etc." (Strauss, 1941). Bakhtin used his analysis of Rabelais and Dostoevsky to contend that dialogue is inevitable in everyday life, generating ambivalence, contradictory perspectives, and inconsistent narratives and must form an integral part of the text, language, and thought. He shunned the monologic authority of the author in designing the fixed and unquestionable interpretation of the text and proposed the use of multiple-voiced discourse to provoke his readers' interest and force them repeatedly read the text to reaffirm its implied meaning. Through the dialogic techniques of carnival, polyphony, and heteroglossia, he imagined his reader to transgress the monochromatic ideologies, liberating himself to form fresh, unique and imaginative alternative perspectives.

Bakhtin's dialogism has been accepted posthumously in NA literature since it aims to liberate its' readers from the trite accounts of melodramatic history, and acts as a tool to invigorate their minds with multiple interpretations of verbal and non-verbal discourse.

\subsection{Iser's Interpretation of Implied Readers}

Wolfgang Iser's stance on readers' contribution in the literary process is attributed to his two major works i.e., The Implied Reader (1974), and The Act of Reading (1979). In these books, the text is interpreted as a collection of incomplete instructions that are completed by the reader, through his imagination and previous experiences. Iser's reader employs the strategy of "wandering viewpoint" to process the text, familiarize with competing perspectives (not necessarily synchronous with his beliefs), and predict outcomes or fill in gaps, based on his enlightened apprehension, and past experiences. He constantly moves back and forth through the text, to confirm and reaffirm the contradicting ideas in the text and is open to revision in his initial opinions. Iser's reader aims to achieve a holistic response from the text and is well aware of the limitations of his pre-mature beliefs that are harnessed before the reading process (Beach, 1993). Iser's (1979) reader "combines all that he sees within his memory and establishes a pattern of consistency, the nature, and reliability of which will depend partly on the degree of attention he has paid during each phase of the journey. At no time, however, can he have a total view of that journey".

Steven Mailloux (2018) in his book Interpretive Conventions criticizes Iser's reader by questioning the ultimate authority given to the author. Although Iser proclaims to give the reader primary importance in the reading process, he instructs the reader to choose from a predefined set of perspectives propagated by the author, ultimately favoring the author's grand plan for the intended meaning of the text. Mailloux (2018) describes the gap-filling act of Iser's reader as a predefined set of instructions, and professes that “... perspectives, blanks, and theme-and-horizon structure constitute the constraints that Iser's account places on the reader's interpretation of the whole text." Similarly, Elizabeth Freund (2013) contends that Iser's theory "presumes both an actively engaged reader employing cognitive strategies to create coherence, while, at the same time, the text's schemata is also considered to be independent of the readers' meaning-making".

It seems that Iser's interpretation of the reader's role is similar to the situation of students in academia who are instructed to bring out alternative interpretations of the text and then forced to adopt a particular perspective. Therefore, we can conclude that Iser's reader isn't as free to exercise his part as a reader and is dependent on the author's projection of potential intended meanings, to arrive at a particular conclusion. Let us examine Vizenor's work in this light and determine how far Iser's implied reader succeeds in achieving closure from Vizenor's Heirs. 


\section{Methodology}

The above mentioned theoretical framework is employed by the authors in this paper to perform a compact analysis of Vizenor's Heirs. Using the collaborative approach, by combining dialogism, and reader-response theory, our claim of dialogic as well as socio-political linkages in the selected work is further intensified and helps the reader in better deciphering the dialogical connotations buried in the text of the selected novel; these linkages also aid in understanding the stance of writer. We have incorporated adequate textual evidence in line of supporting the basic assumptions and make credible claims. Although incorporation of textual evidence is the tool used more often than not, we have also included citations of sources that concur with our claim in order to further validate our findings.

\section{Analysis}

The Heirs was written in communion with the 500th anniversary of the first arrival of Columbus in America. The time of history mentioned in the novel creates a superior presence of White Nation (Eurocentric) in NA World which led to the inevitable loss of life, land, and NA identity. Vizenor has used language games and postmodernist discourse to create subversion of the stereotypes in the history of America. He rejects the idea of America being discovered, instead, he has weaved an imaginary account of Columbus being the descendant of the Native American origin, and the discovery of America is depicted merely as an act of coming back home of Christopher Columbus to his native homeland. Columbus is depicted as "an obscure cross blood who bore the tribal signature of survivance and ascended the culture of death in the Old World" (p. 3). He is mixed blood, as imagined by the writer, and a descendant of both Mayan (Indigenous origin) and Jewish origin. The roots of Columbus' genealogy, therefore, go back to the lost tribes of Israel who traveled further than others towards Europe.

\subsection{Polyphony and Its Intended Meaning}

By giving Columbus a tribal heritage, Vizenor has rendered European claim of discovery of America void, as he writes in the epilogue of the novel that it was never Columbus' intention to settle on Native land and his decision was biased by the destruction of two out of three ships, under his command, at sea. The text is multiple voiced and dialogism is created by combining the historical facts recorded in the Eurocentric books with the NA oral traditions; multiple narrators take hold of the storytelling process and present their versions where each version is unique and never conforms to a single storyline. Dialogic narrative is created by discursive voices of Christopher Columbus and his heirs namely Binn Columbus (mother of Stone Columbus), Stone, Felipa (Stone's partner) and Miigis flowers (Felipa and Stone's daughter); the end of one narrative transcends the beginning of the second narrative giving rise to polyphony of voices. Stone Columbus's narration of Christopher Columbus' stories is often carried on by Christopher Columbus himself, as stories in the blood are common to all heirs of Mayan descent.

In this bizarre New World, these descendants of Columbus are setting out to look for the remains of Columbus and Pocahontas; Felipa is a poacher, in addition to being a lawyer, who "repatriates tribal remains and sacred pouches from museums" (p. 8). Felipa and Stone's character represents the notion of modern Native American as thriving and re-harmonizing individuals who can withstand the criticisms of the western dominated contemporary world; flexibility in their adherence to a particular school of thought, is the quality that Vizenor wants to endow upon his readers. He teaches his readers to adopt mediation as their ally in working through problems of their lives. Vizenor's use of dialogism is the opposite of the established binary oppositions in the society and it is reflected in the novel when the concept of pure blood is deconstructed. Vizenor was strongly against the racial discrimination and he revisits this theme when Stone's sovereign state is threatened by "tribal fascists who would abolish the heirs, their bingo, humor and certain words, such as crossblood, and the genes of survivance" (p. 131). Similarly, the western epistemology rejects the mixed-blood descent of mongrels since they prefer pure blood ties. But the mongrels are presented as the best race, in Hiers, that walks the face of this planet. Vizenor even went the extent to claim that "the best humans" are mongrels: Columbus, Jesus, Mayans, Jews, and Moors. He identifies with Bakhtin's aversion to the hierarchical system of society and believes that through dialogic deconstruction of societal norms, one can achieve multiple perspectives and invoke freedom of expression to its' fullest.

\subsection{NA Oral Tradition, the Reader's Response}

The ambiguity created by Vizenor provokes the reader to cultivate alternative perspectives and the intentional gaps left in the storyline are the source of imaginative response for the reader. The text itself invokes the reader's mind to misinterpret the meaning intended behind it, all the while, creating confusion and chaos throughout the novel. In Heirs, Vizenor's method of storytelling borders on incoherent narration; intentionally creating 
ambiguity with no hint of closure for the reader. Bleaser (1996) on the emersion of ideals from the work of Vizenor asserts in his book Gerald Vizenor: Writing in the Oral Tradition, that, "Vizenor's immersion of events, ideas, and characters in a critical context (are) ... Sometimes factual, sometimes fictional, sometimes both together, scenes and quotations fill Vizenor's work as he juxtaposes the words or ideas of one writer or theorist against those of another, letting the context itself support, incriminate, or interrogate the ideas presented." For example, Stone Columbus is never consistent about his historical account of C. Columbus and changes the details every time; when talking about his link with C. Columbus, he says "Samana ... touched his soul and set the wounded adventurer free on October 28, 1492, at Bahia de Bariay" ... "spell it out in your own words," said Admiral White. "October 29, 1492, at Rio de la Luna." "You changed the date." "Columbus is ever on the move in our stories," said Stone. So far, the Iser's theory is coherent with the Vizenor's expectation from his readers. The intentional gaps and theme-horizon structure has helped the researcher in comprehending the author's as well as reader's role in Heirs.

In the first chapter, Vizenor channels his oral ancestral heritage and tells about Naanabozho as an earth diver trickster who has to climb a high mountain and use his own defecation to create a new world. From the dialogic perspective, this entire story of creation of the new world transgresses the story of creation of earth in Christianity, bridging the gaps in NA oral tribal stories and western epistemology. The satirical and a parodist twist are introduced into the novel to combine humor and pain altogether. The new world created by the trickster Naanabozho, mainly depicts Vizenor's deep yearning for freedom of expression, void of racial, religious and cultural critique; this quest for freedom is transgressing the term 'New World', coined with the discovery of America as land of riches, hope and gold rush for the earlier settlers in America. This New World, established on the foundation of capitalism and racism is open to fresh beginnings and renowned as a land of opportunities. However, this entire concept is subverted by Vizenor in his novel when he mentions Naanabozho to create this world with piles of shit collected by him (p. 5).

\subsection{Carnivalesque Discourse}

Vizenor uses humor to dismantle the established canons of the society. Bakhtin names this phenomenon as carnival and associates it with dialogism. Carnival is perceived as an ongoing social process that provokes laughter by subverting the establishment and traditional constructs of society. Vizenor is using this concept to amalgamate comic laughter emerging from joy and sorrow at the same time. For example, the character of Doric Mitchèd is the physical personification of "tribal fascist" who "pretended to be tribal when his timeworn cross-blood heirs served his economic and political interests" (p. 47); His power tussle with Felipa over medicine pouches takes them to the court, however, fortunately Felipa in not indicted. Nevertheless, Doric succeeds in murdering Felipa to avenge his ego, reclaim his financial loss, and recover Christopher Columbus' remains. Evidently, Vizenor combines the tragic with the comic in Heirs, therefore, the comic effect can never make us forget the underlying painful and violent history of colonization; the noxious gravity of Native American dialogue is never forgotten. Felipa is senselessly murdered while she is trying to restore ashes of Pocahontas. The cold corpse of Felipa was left unaccounted for by the Scotland Yard in the graveyard reminding us the brutal history of Native massacre of the past and "Binn held the moccasins to her ear and said that two men tied her down in a room, one man touched her breasts, the other man with the blood on his check watched and then he injected a poison into her thigh. Felipa dreamed that she was a mistle thrush in the tree over the church, she flew into a wicked storm and never returned ..." (p. 175). Her killers are never convicted; in fact, Scotland Yard closes her case irresponsibly. The entire account is filled with the elements of subversion, humor and satire, often, overshadowing the melancholy and disheartening truths about NA oppression. After the establishment of sovereign state, the heirs use tribal stories, trickster humor and gene therapy to heal the "wounded and the lonesome". "Panda and three robots were trained to heal with humor; their memories held the best trickster stories, and modern variations, that would liberate the mind and heal the bodies of children" (p. 158) who were subjected to abuse on the reservations. Therefore, the darkness of Native American history is clearly visible in the text of the novel and reminds the reader to re-think the stereotypical account of the events that have been presented by the Western World for centuries. Instead of highlighting NA oppression, the aim of Vizenor's text is to bridge the gap between NA culture and western epistemology, is to create survivance literature; a literature that recreates and resists the historic facts to be the final truth and insists on NA ability to overcome the miseries of the past and move on, with hope on their side.

Vizenor sympathizes with Columbus and contends that he was a survivalist who "escaped the culture of death and carried [his] tribal genes back to the New World" (p. 9). The interesting part of this narrative is that Columbus arrival at the Islands of America is the result of Columbus' hearing stories carried "in the blood" that provoke him come back to reclaim his ancestry. "The Admiral of the Ocean Sea" has a clubbed penis and has 
suffered throughout his life, tormented by his deformity. Grotesque humor is, like Columbus' genital dilemma, used to subdue the harshness of post-Columbian era and manifests the Vizenor's ability to use humor in a unique and subverted manner. Ironically, Columbus meets tribal trickster Samana on the night of his arrival and is liberated by their sexual union thereby fathering the heirs. Examples of grotesque humor and sexuality are prevalent in the text as Columbus remembers his encounter with Samana, stating in a secret letter at sea, "his wild pleasures and liberation with a hand talker ... she was the "first woman who moved me from the curse of my secret pain" (p. 31).

\subsection{Heteroglossia}

Vizenor's use of oral literature brings forth heteroglossia in his novel. Bakhtin defines heteroglossia as use of multiple speech genres, different signs and their hidden tensions governed by social, political and cultural backdrop at the time of creation of dialogue. For example, heteroglossia can represent different dialects as in Dickens works; use of oral literature as in Vizenor's work. Now the "hidden tensions" part requires elaboration through an example. The conversation between Doric and Felipa while they argue over the rightful place of medicine pouches containing Columbus' remains is marked with heteroglot text. "Stolen, is the right word," whispered Felipa. "Discover is more accurate," said Doric. "How much are your discoveries?" asked Felipa. (p. 50). Although argument is about medicine pouches but it points to the NA history and "discovery" of the New World in reality. Similarly, the word "stolen" in the argument, points to the western confiscation of native lands. Vizenor's use of language games adds another dimension to the said heteroglot text and renders it more ambivalent, requiring its readers to revisit the history of America with suspicious attitude and question the documented facts rather than accepting them blindly. Here we see that Vizenor diverges from Iser's viewpoint because he requires his readers to derive their own conclusions rather than relying on author's intended interpretation of text.

The narrative of this novel also sets out to criticize the history of colonization that included the wide spread massacre of the natives and that also involves centuries of relocation, persecution, subjugation and victimization of these people. The entire concept of discovering America, according to Vizenor, is demeaning and detrimental to the identity of the Native Americans. Vizenor believes that the word 'Indian' bears no identification, since it is nothing more than a mere misinterpretation created by the white people. Upon first contact the natives are not seen as the humans, instead their inability to understand the foreign language was associated with their poor intellect, Columbus was authorized by the king to take slaves therefore he saw potential for taking the natives as slaves; as mentioned in the novel he writes that, "They ought to make good and skilled servants, for they repeat very quickly whatever we say to them" (p. 4). These lines signify the stereotypical mentality of Columbus as the colonizer who construed a single-minded judgment about the livelihood and purpose of the natives. The above mentioned first entry of Columbus sealed the fate of the Native Americans who were seen nothing more than slaves. Kirkpatrick Sale believes that Columbus in the novel is not depicted as character, instead he is "an idea, manipulated by the author" (Sale, 1991). The second way to present Columbus is through the character of Stone Columbus who emulates Christopher Columbus. The mixed blood heirs are earth-divers: their objective is to submerge into the past and the present contemporary society, by jumping back and forth into the time so much so that they want to regenerate their origins and oppose colonization. Dialogically speaking, there is a constant overlapping of boundaries and time frames of the past and present are comingling to create ambiguity in the text. This ambiguity is provoking active response on behalf of its readers. According to Iser, by selection of single event for subversion in history, author opens up the numerous possibilities of conscientious awareness for reader, insinuating a perpetual dialogue, questioning the un-subverted facets of history. Iser differs from Vizenor's point of view in that he relies on partial authority of author to achieve closure whereas Vizenor celebrates ambivalence and contends that closure is overrated in real life and the reader can change his perspective at any point in reading process. In Trickster of Liberty, Vizenor (2005) shares this point of view by saying that "... words are ambiguous." "The word never has only one use," he said at the seminar. "Every word always has a beyond, sustains several meanings. Behind what discourse says, there is what it means ... and behind what it wants to say there is another meaning, and the process will never be exhausted."

\section{Discussion}

After performing the above mentioned analyses based on the hermeneutic theoretical framework, Vizenor's The Heirs of Columbus has been identified to contain dialogic techniques of carnival, polyphony and heteroglossia. The oppression throughout history and its resulting anger seems to resonate in the hearts of Native Americans and even transcends the lapse of centuries, still igniting the hearts of younger generations. The stereotypical imagery of the Natives which had been honed in by the Western literature is unacceptable to the modern readers and writers. Vizenor's use of dialogism has opened up the concept of alternative perspectives with regard to the 
true identity of Native Americans. Although Vizenor tries not to focus on the victimization of natives, he grieves the massacre of his native brothers by insinuating the death of one of the heirs i.e., Felipa Flowers. Nonetheless, the novel ends on an optimistic note of creation of a sovereign state by Stone Columbus which shelters the broken-hearted children and where tricksters heal their abused bodies and soul with their humor. The art of storytelling by tricksters is what saves the children and "Their best memories held the best trickster stories, and modern variations that would liberate the mind and heal the bodies of children" (p. 158).

During our study we have identified that Iser's reader-response is not enough to understand Vizenor's text since he aims to transcend the realm of conventional norms of text and create ambivalent, subverted, multiple-voiced discourse that celebrates heteroglot thought processes and provokes contradiction and confusion, rather than proving closure.

\section{Conclusion}

Text within The Heirs of Columbus is resonating with Vizenor's use of dialogic techniques to bring forth alternative perspectives in the reader's minds. Vizenor tries to discuss the ideals of native sovereignty by stating that the judge, at the hearing of Stone Columbus case in the novel, says that entire concept of tribal sovereignty "is imaginative ... an idea that is more than metes and bounds in treaties" (p. 7). The idea of the novelist is to create a fresh perspective towards the Native American identity. He disregards viewing the Native Americans only as victims or savages.

Ambivalence of responses is necessary to powerfully nurture the power of imagination. This novel perspective of carnival humor provides us with something new and it can also affect the native people to think differently about history and the horrible encounters between them and the colonizers. Vizenor, it seems, wants nothing more than to re-imagine alternative viewpoints, rejecting the imposition of stereotypes of society. This alternative and less intense way of thinking, in our view will, allow Native Americans to assimilate with the contemporary world and open up new pathways for their future while sustaining a healthy perspective towards past, present and future.

We also contend that the basic techniques of dialogism in Heirs abide by Iser's interpretation of reader's response whereas heteroglossia demands its readers to take active part in interpreting the meaning of text rather than relying on author's accepted set of responses. Conclusively our analysis reveals that there are clear differences in Iser's implied reader and Vizenor's active reader, the former is conformist while the latter is revolutionist in his approach.

\section{References}

Baron, R. (2016). Public folklore dialogism and critical heritage studies. International Journal of Heritage Studies, 22(8), 588-606. https://doi.org/10.1080/13527258.2016.1150320

Barry, N. B. (2002). Postmodern bears in the texts of Gerald Vizenor. Melus, 27(3), 93-112. https://doi.org/10.2307/3250657

Beach, R. (1993). A Teacher's Introduction to Reader-Response Theories (NCTE Teacher's Introduction Series). National Council of Teachers of English, 1111 W. Kenyon Road, Urbana, IL 61801-1096 (Stock No. 50187-0015, \$9.95 members; \$12.95 non-members).

Blaeser, K. M. (1996). Gerald Vizenor: Writing in the oral tradition. University of Oklahoma Press.

Carmack, R. M., Gasco, J. L., \& Gossen, G. H. (Eds.). (2016). The legacy of Mesoamerica: history and culture of a Native American civilization. Routledge. https://doi.org/10.4324/9781315663661

Erdrich, L. (1988). Tracks: a novel.

Erdrich, L. (1993). Love Medicine. New York: Holt.

Fischer, M. M. (1986). Ethnicity and the post-modern arts of memory. Writing Culture: The Poetics and Politics of Ethnography, 194-233.

Freund, E. (2013). Return of Reader. Routledge. https://doi.org/10.4324/9781315016078

Hochbruck, W. (1992). Breaking Away: The Novels of Gerald Vizenor. World Literature Today, 66(2), 274. https://doi.org/10.2307/40148132

Iser, W. (1974). The implied reader: Patterns of communication in prose fiction from Bunyan to Beckett. Johns Hopkins University Press.

Iser, W. (1979). The act of reading (pp. 16-34). Routledge and Kegan Paul. 
Ivanov, V. (1999). Heteroglossia. Journal of Linguistic Anthropology, 9(1/2), 100-102. https://doi.org/10.1525/jlin.1999.9.1-2.100

King, T., \& Bernson, B. (1993). Green grass, running water (Vol. 431). Boston, MA: Houghton Mifflin.

Krupat, A. (1992). Ethnocriticism: Ethnography, history, literature. Univ of California Press.

Lush, R. M. (2012). Turning Tricks: Sexuality and Trickster Language in Vizenor's The Heirs of Columbus. Studies in American Indian Literatures, 24(2), 1-16. https://doi.org/10.5250/studamerindilite.24.2.0001

Mailloux, S. (2018). Interpretive conventions: The reader in the study of American fiction. Cornell University Press. https://doi.org/10.7591/9781501720949

Mielke, L. L. (2018). Native American Presence. Cambridge University Press. https://doi.org/10.1017/9781316271537.005

Momaday, N. S. (1989). The ancient child: a novel. Doubleday Books.

Owens, L. (1994). Other destinies: understanding the American Indian novel (Vol. 3). University of Oklahoma Press.

Russo, B. V. (2017). Deconstructing the Master's House with His Own Tools: Code-Switching and Double-Voiced Discourse as Agency in Gerald Vizenor's Heirs of Columbus. Studies in American Indian Literatures, 29(4), 58-75. https://doi.org/10.5250/studamerindilite.29.4.0058

Sale, K. (1991). Roll on Columbus, roll on. Nation, 253(13), 465-470.

Silko, L. M. (2006). Ceremony. Penguin.

Silko, L. M. (2012). Storyteller. Penguin Group USA.

Strauss, L. (1941). Persecution and the Art of Writing. Social Research, 488-504.

Vizenor, G. (1990). Trickster discourse. American Indian Quarterly, 277-287. https://doi.org/10.2307/1185655

Vizenor, G., \& Vizenor, G. R. (1991). The heirs of Columbus. Wesleyan University Press.

\section{Copyrights}

Copyright for this article is retained by the author, with first publication rights granted to the journal.

This is an open-access article distributed under the terms and conditions of the Creative Commons Attribution license (http://creativecommons.org/licenses/by/4.0/). 